\title{
Balancing Soil Health and Biomass Production
}

\section{Larry E. Erickson and Kraig Roozeboom}

\begin{abstract}
Soil is a living ecosystem with many different microorganisms (bacteria, fungi, and actinomycetes), microfauna (protists and nematodes), mesofauna (arthropods, insects, mites, rotifera), and macrofauna (earthworms, termites, spiders, and isopods). Biodiversity is beneficial to soil health and improving biodiversity as part of a phytoremediation project is very desirable. Adding soil amendments such as compost or manure often improves soil health. Soil organic carbon is an important variable that provides carbon and energy for the organisms. At many sites with contaminants soil organic carbon is low at the start of the project. Soil health affects human health because the concentrations of elements and compounds in harvested fruits and vegetables depend on concentrations in the soil. If zinc concentration is low in a garden soil, there may be zinc deficiency in humans because of low concentrations in food from that garden. This chapter reviews aspects of soil quality and soil health and addresses the importance of improving soil health as part of a phytroremediation project.
\end{abstract}

\section{CONTENTS}

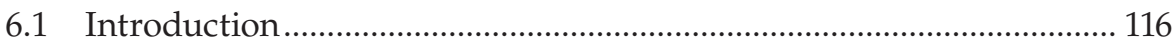

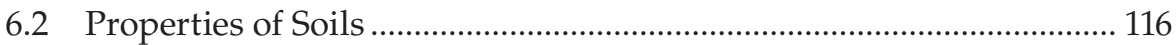

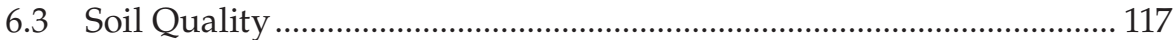

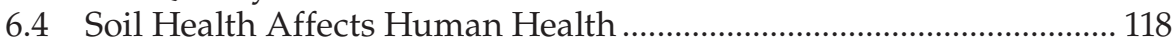

6.5 Improving Soil Health Using Phytotechnology .................................. 119

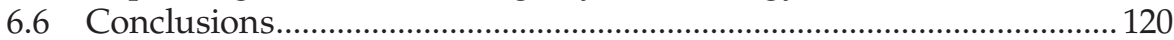

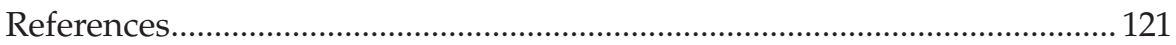




\subsection{Introduction}

Soil health, the capacity of soil to function as a vital living ecosystem, impacts the productivity of soil and ultimately human health. Reversing soil degradation by rebuilding healthy soils is a central theme of the emerging regenerative agriculture movement (Schreefel et al., 2020). Soils contaminated by military or other activities may require additional attention to address contamination and improve soil health. For example, biological organisms in the soil may have been reduced in number because of the contamination.

This chapter addresses the role of phytoremediation in improving soil health in the presence of contaminants. One goal at contaminated sites is to reduce risk of harmful exposure to contaminants, but a concurrent goal can be to improve the soil health sufficiently so the land can provide ecosystem services such as crop production. Soil health can be characterized based on physical, chemical, and biological properties.

Soil health and soil quality have both been used commonly. Soil health often includes the state of a population of living organisms in soil, while soil quality often refers to the physical and chemical state of the soil. Soil health is recognized as a local, regional, and global concern (Karlen \& Rice, 2017). Education, research, and good practices are needed to improve soil quality. Government policies that are designed to improve soil health are beneficial.

\subsection{Properties of Soils}

The physical properties of soils include porosity, bulk density, water-holding capacity, texture, aggregation, infiltration, and penetration resistance. Chemical properties include concentrations of nutrients such as nitrogen, phosphorus, and potassium (N, P, and $\mathrm{K})$, macronutrients such as calcium, micronutrients, such as zinc, organic carbon, $\mathrm{pH}$, salinity, cation exchange capacity, and electrical conductivity (Brady \& Weil, 2002). Biological properties include numbers of microorganisms, earthworms, other fauna, and soil respiration (Whalen \& Sampedro, 2010).

Soil health is related to the measured values of soil properties, but contamination, availability of contaminants, and physical properties such as compaction affect soil health also. Actions to improve soil properties, such as adding amendments and building soil carbon, which is linked to both soil quality and soil health (Blanco-Canqui et al., 2015), can be beneficial to soil health and the phytoremediation process. 


\subsection{Soil Quality}

In the world today, soil quality is poor in many locations. Low concentrations of nutrients and organic carbon result in lower yields. Salinity is an issue in locations where irrigation water has contributed to an increase in salt concentration. In this book, the emphasis is on applications of phytoremediation at contaminated sites. Many of these sites have physical issues because water-holding capacity is poor, porosity is low, and root penetration is difficult because of compaction. Both soil contamination and degraded soil quality must be addressed at many sites.

Soil tilth, the physical state of the soil for growing plants, often needs to be improved at many sites where phytoremediation is used to address contamination. The conditions at the soil surface and the conditions up to $20 \mathrm{~cm}$ below the surface are important for establishing vegetative cover. Good soil drainage and beneficial populations of bacteria, fungi, earthworms, nematodes, and other organisms are desirable (Chauhan \& Mittu, 2015).

Assessment approaches of soil quality and indicators of soil health have been reviewed with respect to soil threats, ecosystem services, and functions (Bünemann et al., 2018). A total of 65 sets of indicators were reviewed; organic carbon, $\mathrm{pH}$, available nitrogen, phosphorus and potassium, water storage, texture, and bulk density were included more than all other indicators. Biological indicators are important but are less commonly included in assessments because of the skills needed; however, including them can improve assessment results. The interpretation of assessment results requires experimental expertise or information on each test and its desired range of values. It is useful to be able to relate the ecosystem services to the values of the measured variables.

The United Nations Sustainable Development Goals include goal 2, which is zero hunger, and goal 15, which is life on land (sustainably manage forests, combat desertification, halt and reverse land degradation, and halt biodiversity loss). This goal 15 includes improving the health of ecosystems by addressing soil health to improve livelihoods. As population increases and quality of life improves, there is a great need to improve soil quality and the productivity of ecosystems that benefit from good soil health. As the effort to reduce greenhouse gas emissions advances and the transition to biodegradable products expands, land is needed for many purposes, and good soil health should become a priority for all countries.

The Food and Agriculture Organization (FAO) estimates that about onethird of soils that are used for agriculture have poor soil quality because of past use and management (FAO, 2011; Jian et al., 2020; Rodríguez-Eugenio et al., 2018). Low soil fertility, nutrient depletion, loss of soil from erosion, and low concentration of organic carbon are common reasons for poor soil quality. In a national survey in China, $16.1 \%$ of soil samples had measured 
values of one or more substances such as lead that exceeded the standards that are recommended for safety (Palansooriya et al., 2020).

Sustainable soil management for all soils is recognized as an important goal for society by FAO, and guidelines and principles have been developed (FAO, 2015, 2017). The guidelines include as follows: (i) minimize soil erosion; (ii) enhance soil organic matter content; (iii) foster soil nutrient balance and cycles; (iv) minimize soil salinization and alkalinization; (v) minimize soil contamination; (vi) minimize soil acidification; (vii) preserve and enhance soil biodiversity; (viii) minimize soil sealing; (ix) prevent and mitigate soil compaction; (x) Improve soil water management. Soil biodiversity and soil organic matter content are related because carbon, nutrients, and energy to support microorganisms and soil fauna are provided by the soil organic matter.

The principles in the soil charter recognize soil as a key resource that provides ecosystem services for food security. Sustainable soil management is based on knowledge of the physical, chemical, and biological state of the soil, and education about soils is beneficial. Global biodiversity of soil organisms is an important resource that needs to be sustained (FAO, 2015).

\subsection{Soil Health Affects Human Health}

Soil health has an impact on human health. The state of physical, mental, and social well-being is important for good human health (Brevik et al., 2020). The goal to create social and physical environments that contribute positively to good human health for all includes high-quality soil health that functions as a vital living ecosystem for growing plants that are beneficial to animal and human health. One example of soil health impacting human health is hypothyroidism/multinodular goiter because of soil deficiency in iodine. Another example is metal concentrations in foods that exceed the acceptable limits based on food safety (Brevik et al., 2020). Brevik et al. (2020) contains extensive tables on (i) properties of soils that may affect human health, such as zinc deficiency; (ii) persistent organic pollutants identified by the Stockholm Convention, such as chlordane; and (iii) human pathogens found in soil, such as Salmonella. Metals in soils are a global problem because of soil contamination associated with military activities, mining, industrial operations, and irrigation of crops with wastewater. The metals find their way into foods and are ingested, and inhalation of dust with metals is of concern. Pesticides are a major concern in many locations because about 25 million people working in agriculture are affected by pesticides each year (Brevik et al., 2020).

Phytoremediation is one of the better methods to improve soil health where pesticide-contaminated soil is found (Tarla et al., 2020). Micro- and macroorganisms in soil affect plant growth and health. Arbuscular mycorrhizal 
fungi have been found to enhance product yields and nutrient content. Plant growth promoting bacteria have been added to soil with beneficial results (Brevik et al., 2020; Pidlisnyuk et al., 2020). Endophytic bacteria and fungi produce enzymes that improve bioremediation of organic contaminants (Fagnano et al., 2020). Earthworms and nematodes are examples of macroorganisms that enhance nutrient cycling and diversity in soils. Earthworms improve soil structure and tilth. They are also impacted by pollutants and their population size is a measure of soil health.

\subsection{Improving Soil Health Using Phytotechnology}

Phytotechnology with biomass production can have multiple goals including (i) addressing contamination; (ii) improving soil health; (iii) improving biomass production of a useful product; (iv) adding soil carbon to improve soil quality and sequester carbon in the soil. Soil amendments may be added at contaminated sites because they are beneficial for the phytoremediation; however, it is desirable in selecting amendments to consider all four of the above goals. Soil amendments can impact $\mathrm{pH}$, microbial populations, nutrient concentrations of $\mathrm{N}, \mathrm{P}, \mathrm{K}$, and organic carbon, porosity, texture, salinity, and trace element concentrations.

A recent review by an international group of authors (Palansooriya et al., 2020) addressed soil amendments for soils containing potentially toxic elements. The authors present three valuable tables with information on a list of potentially toxic elements (As, Ba, Cd, Co, Cr, $\mathrm{Hg}, \mathrm{Ni}, \mathrm{Mn}, \mathrm{Mo}, \mathrm{Pb}, \mathrm{Sb}$, $\mathrm{Se}, \mathrm{V}$ ) including their chemistry in soils; organic soil amendments (animal waste, biochar, biosolids, compost, plant residues) that are beneficial in contaminated soils; and inorganic soil amendments (clay minerals, coal fly ash, industrial waste, liming materials, metal oxides, and phosphates) that have been used. The review includes information on many projects where soil amendments have been applied to reduce the availability of toxic elements.

Many organic soil amendments have beneficial value for soil health because the increase in soil organic matter improves soil structure, water-holding capacity, and nutrient availability. Biomass production is improved, microbial populations are larger, and the ecosystem functions better. The review includes a comprehensive discussion of research with biochar amendments in soils with toxic elements, including some information on 29 field studies reported by O'Connor et al. (2018). The yield with Miscanthus was increased using biochar in one of the studies. In general contaminant bioavailability was reduced by adding biochar, but the magnitude of the effect may decrease when $\mathrm{pH}$ decreases over time. Soil amendments have been reported to be cost-effective and beneficial to soil health and biomass production. When selecting amendments, it is important to evaluate their composition because 
toxic substances, salts, and other contaminants may be present. When using organic amendments at a new site where vegetation is being established, there may be a need to add soil fauna to enhance biodiversity.

In some applications of phytotechnology, there is a need to improve the biological state of the soil in order to improve soil health. The well-developed soil ecosystem includes about four trophic levels of organisms. Archaea, bacteria, fungi, actinomycetes, and algae provide ecosystem services by degrading organic compounds and making nutrients more available to plants. These are very small microorganisms of the order of $1 \mu \mathrm{m}$. Microfauna include protists (protozoa) and small nematodes that consume bacteria and other microorganisms. The microfauna are frequently larger than $2 \mu \mathrm{m}$ and often less than $1 \mathrm{~mm}$. There are soil mesofauna such as arthropods (insects), mites (acari), larger nematodes, and rotifera that are often in the size range between 0.1 and $5 \mathrm{~mm}$. Macrofauna are about $1-50 \mathrm{~mm}$ in size and include earthworms, termites, spiders, and isopods (Whalen \& Sampedro, 2010). Earthworms are very beneficial; they improve the texture of soil and nutrient cycling.

Although not conducted on a contaminated site, research comparing perennial crops such as miscanthus (Miscanthus sacchariflorus) and switchgrass (Panicum virgatum L.) with annual crops such as maize (Zea mays L.) and sorghum [Sorghum bicolor (L.) Moench] as potential cellulosic biofuel feedstocks illustrates the potential for achieving production and soil health goals simultaneously. Ethanol production potential of the perennial crops was less than that of the annual crops but still surpassed $3 \mathrm{~m}^{3} \mathrm{ha}^{-1}$ year $^{-1}$ averaged over 10 years in the Central Great Plains of the US (Roozeboom et al., 2019). In that time, soil organic carbon increased in the $0-15 \mathrm{~cm}$ soil depth beneath perennial crops by $0.8-1.3 \mathrm{Mg} \mathrm{C}$ ha $^{-1}$ year $^{-1}$ (McGowan et al., 2019). Greater soil organic carbon was associated with improvements in several parameters generally associated with greater soil health: root biomass, abundance of arbuscular mycorrhizae and saprophytic fungi, and soil aggregation, which is also associated with reduced soil loss.

\subsection{Conclusions}

Soil health and soil quality are very important because ecosystem services such as crop yields are greater when soil health is very good. In applications of phytoremediation with biomass production, it is beneficial to have multiple goals to reduce the effects of the contamination on soil health and to improve soil health and biomass productivity. Soil amendments that add organic carbon and living organisms may help to improve soil health, plant growth, and nutrient cycling. Education is generally of significant value because of the complexity of soil ecosystems and the many properties of soils that affect soil health and ecosystem services. 


\section{References}

Blanco-Canqui, H., Shaver, T. M, Lindquist, J. L, Shapiro, C. A, Elmore, R. W., Francis, C. A., \& Hergert, G. W. (2015). Cover crops and ecosystem services: Insights from studies in temperate soils. Agronomy Journal, 107, 2449-2474. https://doi. org/10.2134/agronj15.0086

Brady, N. C., \& Weil, R. R. (2002). The Nature and Properties of Soils (13th ed.). Saddle River, NJ: Prentice Hall.

Brevik, E. C., Slaughter, L., Singh, B. R., Steffan, J. J., Collier, D., Barnhart, P., \& Pereira, P. (2020). Soil and human health: Current status and future needs. Air, Soil and Water Research, 13, 1-23. https://doi.org/10.1177/1178622120934441

Bünemann, E. K., Bongiorno, G., Bai, Z., Creamer, R. E., De Deyn, G., de Goede, R., Fleskens, L., Geissen, V., Kuyper, T. W., Mäder, P., Pulleman, M., Sukkel, W., van Groenigen, J. W., \& Brussaard, L. (2018). Soil quality-A critical review. Soil Biology and Biochemistry, 120, 105-125. https://doi.org/10.1016/j.soilbio.2018.01.030

Chauhan, A., \& Mittu, B. (2015). Soil health-An issue of concern for environment and agriculture. Journal of Bioremediation E Biodegredation, 6(3), 1. https://doi. org/10.4172/2155-6199.1000286

Fagnano, M., Visconti, D., \& Fiorentino, N. (2020). Agronomic approaches for characterization, remediation, and monitoring of contaminated sites. Agronomy, 10(9), 1335. https://doi.org/10.3390/agronomy10091335

FAO. (2011). The state of the worlds land and water resources for food and agriculture. Food and Agriculture Organization of the United Nations. http://fao.org.

FAO. (2015). Revised world soil charter. Food and Agriculture Organization of the United Nations. http://fao.org.

FAO. (2017). Voluntary guidelines for sustainable soil management. Food and Agriculture Organization of the United Nations. http://fao.org.

Jian, J., Du, X., \& Stewart, R. D. (2020). A database for global soil health assessment. Scientific Data, 7(1), 16. https://doi.org/10.1038/s41597-020-0356-3.

Karlen, D. L., \& Rice, C. W. (2017). Enhancing Soil Health to Mitigate Soil Degradation. Basel, Switzerland: MDPI. http://mdpi.com/books/pdfview/book/318.

McGowan, A. R., Nicoloso, R. S., Diop, H. E., Roozeboom, K. L., and Rice. C. W. (2019). Soil organic carbon, aggregation, and microbial community structure in annual and perennial biofuel crops. Agronomy Journal, 111, 128-142. https://doi. org/10.2134/agronj2018.04.0284.

O'Connor, D., Peng, T., Zhang, J., Tsang, D. C. W., Alessi, D. S., Shen, Z., Bolan, N. S., \& Hou, D. (2018). Biochar application for the remediation of heavy metal polluted land: A review of in situ field trials. Science of the Total Environment, 619-620, 815-826. https://doi.org/10.1016/j.scitotenv.2017.11.132.

Palansooriya, K. N., Shaheen, S. M., Chen, S. S., Tsang, D. C. W., Hashimoto, Y., Hou, D., Bolan, N. S., Rinklebe, J., \& Ok, Y. S. (2020). Soil amendments for immobilization of potentially toxic elements in contaminated soils: A critical review. Environment International, 134, 105046. https://doi.org/10.1016/j.envint.2019.105046.

Pidlisnyuk, V., Mamirova, A., Pranaw, K., Shapoval, P. Y., Trögl, J., \& Nurzhanova, A. (2020). Potential role of plant growth-promoting bacteria in Miscanthus $\times$ giganteus phytotechnology applied to the trace elements contaminated soils. International Biodeterioration \& Biodegradation, 155, 105103. https://doi. org/10.1016/j.ibiod.2020.105103. 
Rodríguez-Eugenio, N., McLaughlin, M., \& Pennock, D. (2018). Soil pollution: A hidden reality. Food and Agriculture Organization of the United Nations. http://fao.org.

Roozeboom, K. L., Wang, D., McGowan, A. R., Propheter, J. L., Staggenborg, S. A., \& C. W. Rice. (2019). Long-term biomass and potential ethanol yields of annual and perennial biofuel crops. Agronomy Journal, 111, 74-83. https://doi.org/10.2134/ agronj2018.03.0172.

Schreefel, L., Schulte, R. P. O., de Boer, I. J. M., Pas Schrijver, A., \& van Zanten, H. H. E. (2020). Regenerative agriculture - The soil is the base. Global Food Security, 26, 100404, https://doi.org/10.1016/j.gfs.2020.100404.

Tarla, D. N., Erickson, L. E., Hettiarachchi, G. M., Amadi, S. I., Galkaduwa, M., Davis, L. C., Nurzhanova, A., \& Pidlisnyuk, V. (2020). Phytoremediation and bioremediation of pesticide-contaminated soil. Applied Sciences, 10(4), 1217. https://doi. org/10.3390/app10041217.

Whalen, J. K., \& Sampedro, L. (2010). Soil Ecology and Management. Vol. 8. São Paulo, Brazil: CABI. 